RESEARCH ARTICLE

\title{
KAJIAN HUKUM TERHADAP PENOLAKAN PENGOBATAN AKIBAT TERPAPAR COVID 19
}

\author{
Pandam Bayu Seto Aji \\ Universitas Sebelas Maret \\ ajik0204@student.uns.ac.id
}

\begin{abstract}
Criminal Law regulates punishable acts, which are technically referred to as "criminal acts." The Covid19 protocol is one of the efforts to deal with outbreaks of infectious diseases. Because preventing disease transmission is mandatory, refusing Covid19 Treatment is against the law. This research uses empirical legal research. If the perspective of Criminal Law is used to analyze the refusal of Covid-19 treatment, the question that arises is whether refusing Covid-19 treatment is a punishable act. To answer this question, it is necessary to look carefully at the existing laws and regulations, whether rejecting the Covid-19 Treatment is a criminal offense.
\end{abstract}

Keywords: criminal law, rejection of the covid 19 protocol, laws and regulations

Hukum Pidana mengatur tentang perbuatan-perbuatan yang dapat dipidana, yang secara teknis disebut dengan istilah "tindak pidana." Protokol Covid-19 merupakan salah satu upaya penanggulangan wabah penyakit menular. Karena mencegah penularan penyakit bersifat wajib, maka menolak Pengobatan Covid19 merupakan tindakan melanggar hukum. Penelitian ini menggunakan jenis penelitian hukum empiris. Bila perspektif Hukum Pidana digunakan untuk menganalisis penolakan pengobatan Covid-19, maka pertanyaan yang muncul adalah, apakah menolak pengobatan Covid-19 termasuk perbuatan yang dapat dipidana. Untuk menjawab pertanyaan tersebut, perlu dilihat secara cermat di dalam peraturan perundang-undangan yang ada, apakah menolak Pengobatan Covid-19 merupakan tindak pidana.

Kata Kunci: hukum pidana, penolakan pengobatan covid 19, peraturan perundangundangan 


\section{INTRODUCTION}

Ada berbagai bentuk pelanggaran protokol Covid-19, tetapi yang menjadi fokus pembahasan hanya yang terkait dengan isu penolakan pengobatan seperti pada kasus berikut: "Terhadap pasien suspek Covid-19, dokter melakukan pemeriksaan rapid dan hasilnya reaktif. Dokter lalu memutuskan untuk melanjutkan dengan pemeriksaan swab. Tetapi pasien menolak untuk diobati walau sudah mendapat penjelasan lengkap, memadai dan berkali-kali.

\section{Rumusan Masalah}

a) Apakah menolak pemeriksaan dapat dipidana?

b) Apakah melakukan pemeriksaan tanpa persetujuan pasien secara hukum bisa benarkan?

\section{RESULT \& DISCUSSION}

\section{A. Rujukan}

a) Undang-undang Nomor 36 Tahun 2009 Tentang Kesehatan

b) Peraturan Menteri Kesehatan Nomor 82 Tahun 2014 Tentang Penanggulangan Penyakit Menular

c) Undang-undang Nomor 4 Tahun 1984 Tentang Wabah Penyakit Menular;

d) Peraturan Pemerintah Nomor 40 Tahun 1991 Tentang Penanggulangan Wabah Penyakit Menular

e) Keputusan Menteri Kesehatan Nomor HK.01.07/MENKES/382/2020 Tentang Protokol Kesehatan bagi Masyarakat di Tempat dan Fasilitas Umum dalam rangka Pencegahan dan Pengendalian Covid-19.

f) Instruksi Presiden Nomor 6 Tentang Peningkatan Disiplin dan Penegakan Hukum Protokol Kesehatan dalam Pencegahan dan Pengendalian Corona Virus Disease 2019.

\section{UNDANG-UNDANG NOMOR 36 TAHUN 2009 TENTANG KESEHATAN}

Pasal 56 (1): "Setiap orang berhak menerima atau menolak sebagian atau seluruh tindakan pertolongan yang akan diberikan kepadanya setelah menerima dan memahami informasi mengenai tindakan tersebut secara lengkap. Pasal 56(2): "Hak menerima atau menolak sebagaimana dimaksud pada ayat (1) tidak berlaku pada:

a. Penderita penyakit yang penyakitnya dapat secara cepat menular ke dalam masyarakat yang lebih luas.

b. Keadaan seseorang yang tidak sadarkan diri; atau

c. Gangguan mental berat

Pasal 157 (1): "Pencegahan penularan penyakit menular wajib dilakukan oleh masyarakat termasuk penderita penyakit menular melalui pola hidup bersih dan sehat. Penjelasan Pasal 157 (1): "Perilaku hidup bersih dan sehat bagi penderita penyakut menular dilakukan dengan tidak melakukan tindakan yang dapat memudahkan penularan penyakit pada orang lain.

Pada Peraturan Menteri Kesehatan Nomor 82 Tahun 2014 Tentang Penaggulangan Penyakit Menular. Setiap orang yang mengetahui adanya penderita penyakit menular berkewajiban melaporkan kepada tenaga kesehatan atau puskesmas. 
Tenaga kesehatan sebagaimana dimaksud pada ayat (1) harus melaporkan kepada Puskesmas untuk dilakukan verifikasi, pengobatan, dan upaya lain yang diperlukan agar tidak terjadi penularan penyakit.

Pejabat Kesehatan Masyarakat pada satuan kerja Pemerintah dan Pemerintah Daerah dalam rangka menyelenggarakan program penanggulangan penyakit menular memiliki tugas mengambil dan mengirim sampel dan/atau spesimen untuk keperluan konfirmasi laboratorium.

Pasal 1 butir (3): Pejabat Kesehatan Masyarakat adalah PNS di lingkungan kesehatan yang mempunyai tugas dan wewenang di bidang penanggulangan penyakit menular.

Kemudian pada Undang-Undang Nomor 4 Tahun 1984 Tentang Wabah Penyakit Menular. Upaya penanggulangan wabah meliputi:

a) Penyelidikan epidemiologis;

b)Pemeriksaan, pengobatan, perawatan, dan isolasi penderita, termasuk tindakan karantina;

c) Pencegahan dan pengebalan;

d) Pemusnahan penyebab penyakit;

e) Penanganan jenazah akibat wabah;

f) Penyuluhan kepada masyarakat;

g) Upaya penanggulangan lainnya.

Pasal 14 (1): Barangsiapa dengan sengaja menghalangi pelaksanaan penanggulangan wabah sebagaimana diatur dalam undang-undang ini, diancam dengan pidana penjara selama-lamanya 1 (satu) tahun dan/atau denda setinggitingginya Rp.1.000.000. $\theta$ Pasal 14 (2): Barangsiapa karena kealpaannya mengakibatkan terhalangnya pelaksanaan penanggulangan wabah sebagaimana diatur dalam undang-undang ini, diancam dengan pidana kurungan 6 (enam) bulan dan/atau denda setinggi-tingginya Rp.500.000.

Hal ini juga diatur pada Peraturan Pemerintah Nomor 40 Tahun 1991 Tentang Penanggulangan Wabah Penyakit Menular

"Upaya penanggulangan wabah adalah segala upaya yang ditujukan untuk memperkecil angka kematian, membatasi penularan serta penyebaran penyakit agar wabah tidak meluas ke daerah lain”. Pasal 6 (1): Menteri (Kesehatan) bertanggung jawab atas pelaksanaan teknis upaya penanggulangan wabah.

Dalam Peraturan Kepmenkesno. Hk.01.07/Menkes/382/2020 Tentang Protokol Kesehatan Bagi Masyarakat Di Tempat Dan Fasilitas Umum meliputi :

1. Perlindungan Individu:

a) Menggunakan masker;

b) Membersihkan tangan

c) Menjaga jarak minimal 1 meter

d) Meningkatkan daya tahan tubuh

2. Perlindungan Kesehatan Masyarakat:

a) Unsur Pencegahan:

1) Promosi Kesehatan;

2) Perlindungan (termasuk penegakan kedisiplinan pada perilaku masyarakat yang beresiko dalam penularan dan tertularnya Covid 19 seperti berkerumun, tidak mengenakan masker, merokok di tempat dan fasilitas umum, dsb.

b) Unsur Penemuan Kasus: (termasuk pemantauan kondisi kesehatan terhadap semua orang yang ada di tempat atau fasilitas umum). 
c) Unsur Penanganan Cepat (termasuk pelacakan kontak erat, pemeriksaan rapid test atau Real Time Polymerase Chain Reaction (RT-PCR) serta penanganan lain sesuai kebutuhan.

Berdasarkan Pada Instruksi Presiden Nomor 6 Tahun 2020 Tentang Peningkatan Disiplin Dan Penegakan Hukum Protokol Kesehatan Dalam Pencegahan Dan Pengendalian Covid 19

Instruksi kepada para Gubernur, Bupati dan Walikota agar (antara lain) menyusun dan menetapkan peraturan gubernur/peraturan bupati/peraturan walikota yang memuat ketentuan tentang kewajiban mematuhi protokol kesehatan yang memuat sanksi berupa:

a) Teguran lisan atau teguran tertulis;

b) Kerja Sosial;

c) Denda Administratif; atau

d) Penghentian atau penutupan sementara penyelenggaraan usaha

\section{B. Analisis Hukum}

Terkait kasus yang di atas, tindakan pasien menolak pemeriksaan swab lebih merupakan bentuk pelanggaran hukum administrasi dari pada pelanggaran hukum pidana. Oleh karenanya, tindakan tersebut tidak sampai membawa akibat hukum berupa pemidanaan. Jika merujuk pada INPRES No. 6 Th. 2020, spiritnya lebih kearah pengenaan sanksi administratif, bukan pidana.

Memang ada ancaman pidana terhadap upaya menghalangi penanggulangan wabah penyakit (Pasal 14 Undang-undang Nomor 4 Tahun1984), tapi sekedar menolak pengobatan, (belum) bisa dikualifikasikan sebagai 'perbuatan menghalangi'. Suatu perbuatan bisa disebut 'menghalangi upaya penanggulangan wabah' apabila perbuatan tersebut secara nyata menimbulkan akibat berupa terhalangnya upaya penanggulangan wabah tersebut.

Tindakan pasien menolak untuk diperiksa tidak sampai menimbulkan akibat terhalangnya pemeriksaan karena ada posibilitas bagi petugas untuk menggunakan upaya paksa, yaitu tetap mengupayakan pemeriksaan meskipun tidak mendapat persetujuan pasien. Logikanya, jika petugas boleh menjemput paksa pasien Covid 19 untuk diisolasi, maka sekedar memaksa melakukan pemeriksaan terhadap pasien tentu lebih bisa dimaklumi.

Upaya paksa tersebut konteksnya bukan pemeriksaan yang dilakukan seketika itu, tetapi pemeriksaan yang dilakukan oleh Petugas yang berwenang. Respon yang tepat terhadap penolakan pemeriksaan tersebut adalah dengan melaporkan kasus tersebut kepada pihak yang berwenang (Gugus Tugas Penanggulangan Covid). Mereka inilah yang akan menindak lanjuti melakukan pemeriksaan. Upaya paksa tersebut tidak melanggar hukum karena dilakukan dalam rangka melaksanakan ketentuan undang-undang. Dalam hukum pidana, melaksanakan ketentuan undang-undang diakui sebagai salah satu alasan penghapus pidana (strafuitsluitingsgronden) (R. Soesilo, 1995).

\section{CONCLUSION}

Menolak pengobatan pasien positif covid 19 adalah perbuatan melanggar hukum tetapi bukan merupakan tindak pidana, sehingga pasien yang menolak untuk diperiksa tidak dapat dipidana. 
Undang-undang memperbolehkan Petugas yang berwenang untuk menggunakan upaya paksa terhadap pasien yang menolak diperiksa (melakukan pemeriksaan tanpa persetujuan pasien).

\section{REFERENCES}

\section{A. Buku}

Soesilo, R., 1985. Kriminologi (Pengetahuan Tentang Sebab-Sebab Kejahatan, Bogor: Politeia.

\section{B. Undang-Undang}

Undang-undang Nomor 36 Tahun 2009 Tentang Kesehatan

Peraturan Menteri Kesehatan Nomor 82 Tahun 2014 Tentang Penanggulangan Penyakit Menular Undang-undang Nomor 4 Tahun 1984 Tentang Wabah Penyakit Menular;

Peraturan Pemerintah Nomor 40 Tahun 1991 Tentang Penanggulangan Wabah Penyakit Menular Keputusan Menteri Kesehatan Nomor HK.01.07/MENKES/382/2020 Tentang Protokol Kesehatan bagi Masyarakat di Tempat dan Fasilitas Umum dalam rangka Pencegahan dan Pengendalian Covid-19.

Instruksi Presiden Nomor 6 Tentang Peningkatan Disiplin dan Penegakan Hukum Protokol Kesehatan dalam Pencegahan dan Pengendalian Corona Virus Disease 2019. 